Canada, Australia, and New Zealand. Expansion and improvement has taken place in the Air-Sea Rescue Service operating wherever the Allied air services are called upon to fly across the sea. An interesting variant of this, organized on similar lines, is the African desert rescue service, which has already saved about a hundred lives.

Another innovation is the introduction of a Commando Servicing Unit. Skilled mechanics, armed and trained to fight when necessary, are able to repair damaged aircraft under conditions that would normally mean their abandonment, and a very great saving in equipment has resulted. Tribute was also paid to the R.A.F. regiment, which has constantly been in the van of the advancing infantry, and has been able to re-condition enemy airfields even under fire. The effect of our bombing raids on Germany and the occupied countries goes far beyond the actual hold-up in the production of war material. Damage to transport systems and related workshops disorganizes the even flow of supplies to works, and delays the transport of troops to areas where they are required. The materials and labour necessary for the repair of damaged buildings also has to be diverted from war production.

\section{Sir Bennett Melvill Jones, C.B.E., F.R.S.}

Sir Bennett Melvill Jones, whose appointment to succeed Sir Henry Tizard as chairman of the Aeronautical Research Committee has been announced, has had a long ànd distinguished connexion with the scientific side of aeronautics. While his interests have ranged over almost the entire field of the subject, his name is more particularly associated with the elucidation of the problems arising out of the performance of aircraft. His work has resulted in a steady increase in the eiticiency of the flying machine as a whole, and this, particularly when devoted to raising the speed of flight, has set problems in stability and control that have called for complex and systematic investigation both in the laboratory and in actual flight. Following his student days at Cambridge he took up aeronautics at the National Physical Laboratory, Teddington, and so far back as 1912 contributed a paper to the old Advisory Committee for Aeronautics on the properties of aerofoils. A paper on the stability of kite balloons (1915) was another contribution of his that laid the foundation of the systematic study of stability in flight. He then spent a period with Messrs. Armstrong Whitworth on the development of rigid airships, and followed this by work at the Royal Aircraft Establishment, Farnborough, on flight research. During the War of 1914-i8 he was a member of the Experiment and Research Department of the newly constituted Air Board, and took an active part in the development of aerial warfare, particularly aerial gunnery, principally at the Experimental Station at Martlesham Heath.

Later, Melvill Jones was appointed Francis Mond professor of aeronautics in the University of Cambridge, a post which he still holds, and also became a member of the Aeronautical Research Committee. During that period he has contributed much to the development of those outlooks on aeronautics which he has made his own. He has been able to combine his theoretical work at the University with actual full-scale flying experiment at the R.A.F. station at Duxford. One of his most noted achievements during that period was to present a conception of the ideal streamlined aeroplane, suggesting general rules for its design that quickly received universal acceptance. During the present War he has been principally concerned with the development of fighting technique. He was elected a fellow of the Royal Society in 1939 and received his knighthood in 1942 .

\section{Royal Astronomical Society Gold Medallist}

As already announced, the Gold Medal of the Royal Astronomical Society has been awarded to Dr. H. Spencer Jones, Astronomer Royal, for his determination of the solar parallax from observations of the minor planet Eros, made at the very favour. able opposition of 1931. The solar parallax is a fundamental unit and is the astronomer's disguise for the principal astronomical unit of distance, namely, the mean distance of the earth from the sun. Dr. Spencer Jones' result for the solar parallax (v. Mon. Not. Roy. Ast. Soc., 101, 356; 1941) is $8 \cdot 790^{\prime \prime} \pm 0.001^{\prime \prime}$ and the corresponding mean distance of the earth from the sun is $93,003,000$ miles ; in each case the accuracy is of the order of 1 part in 10,000 . Such an achievement is remarkable, and the Society's award will be acclaimed by astronomers all over the world as an honour deservedly bestowed and brilliantly earned.

The actual observations of Eros, made photographically at about a score of observatories, are represented by nearly three thousand plates; in addition, the positions of several hundreds of primary reference stars and nearly six thousand fainter secondary stars had to be determined. The successful planning of an international campaign of this magnitude was, in itself, no mean feat. The discussion of the immense amount of observational material secured has evidently been thorough, and the Astronomer Royal appears to have overlooked no possible source of error. The Eros observations also provide means of determining accurately the moon's mass and the constant of nutation: the value of the latter is found to be inconsistent with the value usually accepted, and the Astronomer Royal's next activity would seem to be the resolution of this discrepancy.

\section{A New Method of Etching on Metals}

A NEW electrolytic process of etching on metals makes use of a standard waxed-paper stencil such as is used in a duplicating machine, on which is cut the required design. This is placed between the metal article, which forms the anode, and an absorbent pad containing the etching reagent, which is connected to the cathode of a 15 -volt D.C. circuit. The apparatus consists of a unit comprising the transformer, rectifier and output controller, giving a 15-volt D.C. supply from the 200/230-volt A.C. mains. When etching stainless materials, each stencil is good for at least fifteen etchings, or for about ten with less resistant alloys. The normal depth of attack is about 0.0005 in., and curved and irregular articles can be treated. The process is adapted to the marking of tools, plates, etc. The equipment is obtainable from Messrs. Griffin and Tatlock, Ltd., Kemble Street, Kingsway, London, W.C.2.

\section{Training of Civil Servants}

THE Chancellor of the Exchequer has announced that he has set up the following committee to consider the training of Civil servants: The Financial Secretary to the Treasury (Mr. Assheton), chairman; Sir Harold Hartley, vice-president, London Midland 
and Scottish Railway Company; Sir Kenneth Lee, chairman, Tootal Broadhurst Lee Company, Limited; Miss Myra Curtis, principal, Newnham College, Cambridge; Mr. A. J. T. Day, chairman, staff side, National Whitley Council ; Mr. A. L. N. D. Houghton, staff side, National Whitley Council ; Sir Thomas Gardiner, director-general, General Post Office ; Sir Robert Wood, deputy secretary, Board of Education and Mr. H. Wilson Smith, under-secretary, Treasury. The terms of reference of the Committee are: "To examine the general question of the training of Civil servants, including the question whether a Staff College should be established, and if so, the particular form and character which that college should take".

\section{Earthquake in Mid-Atlantic}

The United States Coast and Geodetic Survey, in co-operation with Science Service and the Jesuit Seismological Association, has determined the provisional epicentre of the earthquake of December 31 which took place at about $12 \mathrm{~h} .03 \cdot 7 \mathrm{~m}$. U.T. The instrumental data on which the calculations were based were obtained from the observatories at St. Louis, Tucson, Sitka, San Juan, Burlington, Pasadena, Spring Hill, Lincoln, Huancayo and Fordham. The epicentre turned out to be in the vicinity of latitude $18 \cdot 1^{\circ} \mathrm{N}$., longitude $47.0^{\circ} \mathrm{W}$. This is in the region of the mid-north-Atlantic ridge between Puerto Rico (West Indies) and the Cape Verde Islands. Earthquakes are known to occur in this region from time to time and it would be interesting to have reports of the shock from ships which may have been in the region at the time.

\section{Comet Oterma (1942f)}

Dr. WhrPple has computed the following elements of this comet :

$\left.\begin{array}{rcc}T & 1942 & \multicolumn{2}{l}{\text { December } 18 \cdot 859} \\ \omega & 358^{\circ} & 03 \cdot 0^{\prime} \\ \Omega & 78 & 30 \cdot 8 \\ i & 17 & 57 \cdot 6 \\ a & 11.9604 \\ e & 0.86622 \\ P & 41.4 \text { years. }\end{array}\right\} 1942 \cdot 0$

Its positions for a few dates in April are given below. For intermediate dates it will be sufficiently accurate to interpolate, allowing a daily motion in R.A. $+2 \cdot 7 \mathrm{~m}$. during April 2-12 and $+2 \cdot 2 \mathrm{~m}$. during April 12-28. The corresponding figures in declination are $-0 \cdot 2^{\circ}$ and $-0 \cdot 1^{\circ}$. It is not an easy object to find as its magnitude in the middle of the month, assuming the $p^{2} r^{4}$ law, is about $13 \cdot 5$.

$\begin{array}{cllrrr}\text { Date } 1943 & & \text { R.A. } & \text { Dec. } & \rho & r \\ \text { April } 2 \cdot 0 \mathrm{~d} . & \text { 7h. } 02 \cdot 2 \mathrm{~m} . & +40 \cdot \theta^{\circ} & 1 \cdot 723 & 2 \cdot 038 \\ 12 & 7 & 29 \cdot 5 & 38 \cdot 9 & 1 \cdot 957 & 2 \cdot 121 \\ 28 & 8 & 05 \cdot 3 & 37 \cdot 1 & 2 \cdot 207 & \mathbf{2} \cdot 239\end{array}$

\section{Comet Whipple (1942g)}

ThIs comet is no longer a naked-eye object but can be seen with the aid of a small telescope. Positions are given for the early part of April.

\begin{tabular}{clcrrr} 
Date 1943 & \multicolumn{2}{c}{ R.A. } & Dec. & $\rho$ & \multicolumn{1}{c}{} \\
April 2.0d. & 12h. $42 \cdot 9 \mathrm{~m}$. & $+46 \cdot 5^{\circ}$ & $0 \cdot 729$ & $1 \cdot 565$ \\
6 & 12 & $44 \cdot 3$ & $44 \cdot 9$ & $\cdot 762$ & .594 \\
10 & 12 & $45 \cdot 6$ & $43 \cdot 3$ & $\cdot 796$ & $\cdot 624$
\end{tabular}

\section{The Night Sky in April}

New moon occurs on April 4d. 21h. 53m. U.T., and full moon on April 20d. $11 \mathrm{~h}$. $11 \mathrm{~m}$. Conjunctions with the moon are as follows : April 7 d. 11 h., Venus $6^{\circ}$ N. ;
April 9d. 01h., Saturn $3^{\circ}$ N. ; April 12d. 05h., Jupiter $3^{\circ}$ N. ; April $29 \mathrm{~d}$. 17h., Mars $0 \cdot 1^{\circ} \mathrm{S}$. Occultations of stars brighter than magnitude 6 are as follows : April 16d. 22h. 16m., $\chi$ Leo $(D)$; April 18d. 21h. 55.3 m., $\gamma$ Vir. $(D)$; April 18d. 22h. $43 \cdot 2 \mathrm{~m} ., \gamma$ Vir $(R)$; April 25 d. $03 \mathrm{~h} .42 \cdot 6 \mathrm{~m} ., 21 \mathrm{Sgr} .(R)$. The times are given for Greenwich and $D$ and $R$ refer to disappearance and reappearance respectively. Mercury is in superior conjunction on April 4, reaching its greatest eastern elongation on April 30 when it sets about 2lh. 25m., two hours after sunset. Venus, an evening star, is in conjunction with Saturn on April 25d. 04h., Venus $3 \cdot 1^{\circ} \mathrm{N}$. Mars souths at $8 \mathrm{~h} .34 \mathrm{~m}$. in the middle of the month, but is too low for favourable observation in Great Britain. Jupiter souths at $17 \mathrm{~h} .42 \mathrm{~m}$. in the middle of the month and is well placed for observation in the earlier portion of the night. Saturn sets about $23 \mathrm{~h}$. in the middle of the month and will soon be too close to the sun for favourable observation. Times of setting are given approximately for the latitude of Greenwich. The Lyrid shower of meteors, April 18-24, which has not been very strong in recent years, will not be easily observed owing to moonlight.

\section{Announcements}

Dr. Karl T. Compton, president of the Massachusetts Institute of Technology, will deliver the Pilgrim Trust Lecture before the Royal Society on May 6: he will speak on "The Organization of American Scientists for the War'.

The trustees of the Ray Lankester Fund have appointed Dr. Shu-Ping Chu, of Queen Mary College, University of London, as investigator for 1943-44 to carry out research at the Plymouth Laboratory of the Marine Biological Association into the effect on the development of marine algæ of the presence or absence of different substances in sea water.

The following appointments in the Colonial Service are announced : R. A. Hutchinson, to be veterinary officer, Gambia; A. R. J. McGregor and E. J. Westcott, to be veterinary officers, Nigeria; C. B. Garnett, senior agricultural officer, to be assistant director of agriculture, Nyasaland.

A CORRESPONDENT of The Times writing from Gibraltar states that tunnellers of the Royal Engineers working there have discovered a hitherto unknown cavern. It is said to be of extraordinary beauty, with white, grey and red stalactite columns, and contains a lake of fresh water nearly 40 yards long and $7 \mathrm{ft} .-20 \mathrm{ft}$. deep. The largest column is $7 \mathrm{ft}$. in diameter and $40 \mathrm{ft}$. high.

A USEFUL $16 \mathrm{pp}$. brochure on the preparation and preservation of insects for collections has been written by J. Manson Valentine of the U.S. Department of Agriculture and is published as No. 6, vol. 103 of the Smithsonian Miscellaneous Collections (November 1942). Although it has particular reference to the order Coleoptera it will be found applicable to some other orders of insects also. The methods of mounting, preserving, relaxing, labelling, etc., and other treatment of specimens are clearly described. Some of the technique explained will be found useful and more especially by British workers who are not always familiar with American methods. 